\title{
Association between cigarette smoking status and voting intentions: Cross sectional surveys in England 2015-2020
}

Sharon Cox ${ }^{1 *}$, Jamie Brown ${ }^{1}$, Cheryl McQuire ${ }^{2,3}$, Frank de Vocht ${ }^{2,3}$, Emma Beard $^{1}$, Robert West ${ }^{1}$ and Lion Shahab ${ }^{1}$

\begin{abstract}
Background and aims: Cigarette smoking takes place within a cultural and social context. Political views and practices are an important part of that context. To gain a better understanding of smoking, it may be helpful to understand its association with voting patterns as an expression of the political views and practices of the population who smoke. This study aimed to assess the association between cigarette smoking and voting intentions and to examine how far any association can be explained by sociodemographic factors and alcohol use.
\end{abstract}

Methods: Pooled monthly representative repeat cross-sectional household surveys of adults (16+) in England $(N=$ 55,482) between 2015 and 2020 were used to assess the association between cigarette smoking status and voting intentions, and whether this was accounted for by age, occupational grade, gender, region and alcohol use. Voting intention was measured by asking 'How would you vote if there were a General Election tomorrow?' Respondents chose from a list of the major English political parties or indicated their intention not to vote.

Results: In adjusted multinomial regression, compared with intending to vote Conservative (majority party of government during the period), being undecided (aOR1.22 [1.13-1.33] $<0.001$ ), intending to vote Labour (aOR1.27 [1.16-1.36] <0.001), to vote "Other" (aOR1.54 [1.37-1.72] <0.001), or not to vote (aOR1.93 [1.77-2.11] <0.001) was associated with higher odds of current relative to never smoking rates. Intending to vote for the Liberal Democrats was associated with a significant lower odds of current smoking prevalence (aOR0.80 [0.70-0.91] <0.001) compared with intending to vote Conservative.

Conclusions: Controlling for a range of other factors, current as compared with never-smokers appear more likely to intend not to vote, to be undecided, to vote for Labour or a non-mainstream party, and less likely to vote for the Liberal Democrats, compared with the Conservative party.

Keywords: Tobacco, Health inequality, Inequity, Political participation, Health behaviour, Voting, Smoking

\footnotetext{
*Correspondence: s.cox@ucl.ac.uk

1 Department of Behavioural Science and Health, University College London, 1-19 Torrington Place, London, UK

Full list of author information is available at the end of the article
}

\begin{abstract}
Introduction
Poor general health, wealth inequality and higher mortality are all negatively associated with voter turnout [1-3]. Of a range of health behaviours, evidence shows cigarette smoking status is strongly negatively correlated with poor voter turnout [4], although the reasons why are not well established. It is unlikely that smoking directly influences voting, but instead because of a shared association
\end{abstract}

(c) The Author(s) 2021. Open Access This article is licensed under a Creative Commons Attribution 4.0 International License, which permits use, sharing, adaptation, distribution and reproduction in any medium or format, as long as you give appropriate credit to the original author(s) and the source, provide a link to the Creative Commons licence, and indicate if changes were made. The images or other third party material in this article are included in the article's Creative Commons licence, unless indicated otherwise in a credit line to the material. If material is not included in the article's Creative Commons licence and your intended use is not permitted by statutory regulation or exceeds the permitted use, you will need to obtain permission directly from the copyright holder. To view a copy of this licence, visit http://creativecommons.org/licenses/by/4.0/. The Creative Commons Public Domain Dedication waiver (http://creativeco mmons.org/publicdomain/zero/1.0/) applies to the data made available in this article, unless otherwise stated in a credit line to the data. 
with social disadvantage, it is a wider set of health, social and cultural factors that influences political beliefs and participation [3, 5]. However, because smoking is also more prevalent within poorer communities, by not voting, it is possible smokers from the most disadvantaged communities are underrepresented in elections. This is a disadvantage because communities with higher numbers of smokers are particularly affected by the spending priorities of political parties since these determine resources for tobacco control activities. Given the substantial health burden and inequalities caused by smoking [6], and the pivotal role that political parties have in smoking prevention measures and health and community spending, it is important to understand how sociodemographic characteristics, smoking behaviours and voting intentions are linked. The purpose of this study is to examine the association of smoking status, and sociodemographic characteristics, with voting intentions in England between 2015 and 2020.

Tobacco smoking is a community health issue, disproportionately affecting individuals and families of lower economic status by reducing life expectancy and increasing morbidity; general health is poorer among life-time smokers than never-smokers [7]. Tobacco retail outlet density is positively correlated with neighbourhood deprivation [8], at the same time reductions to smoking cessation services have been highest in the most deprived areas of England [9]. While there has been a reduction in smoking prevalence across the socioeconomic gradient, substantial tobacco related health inequalities remain [10-13]. In England, tobacco smoking rates are currently twice as high in those in routine and manual occupations $(20.8 \%)$ compared with managerial and professional occupations (9.9\%) [14]; prevalence rates are even higher amongst those with competing health and social needs (e.g., experiencing homelessness or insecure housing, food poverty) $[7,15]$. Taken together, this underlines that tobacco smoking continues to be a large contributor to health and social inequalities. Political parties committed to improving community health should be focusing on the burdens caused by tobacco smoking, especially in view of the latest promises by the UK Government to 'level up' the opportunities for those living in deprived towns through increased social participation and mobility [16].

Previous research from Britain and the Republic of Ireland has shown that a greater proportion of smokers do not vote $[1,3,4]$. One study in Britain measuring the relationship between voting behaviour and indicators of health showed smokers were consistently less likely to turnout to vote across the 1979, 1987 and 1997 general elections [4]. When people who smoke do vote, their political party affiliation has not been well documented.
In the few published examples examining poor health, and voting more broadly, patterns of voting are mixed. For example, in the 2017 French presidency elections, poorer health status was positively correlated with voting for far-right candidate Marie Le-Pen compared with voting for centrist candidate Emmanuel Macron, the current president [17]. In the 1997 general election in the Republic of Ireland, however, indicators of deprivation, self-reported poorer quality of life health status, and smoking were correlated with left-wing voting even within a traditionally right-leaning ruling country [1]. In Sweden, one study showed higher political mistrust among daily smokers, with those reporting high distrust or no opinion on government also being less likely to report trying to quit [18]. While in England there have been no studies directly examining trust in political parties or systems among smokers, there have been media stories and reports of the tobacco industry providing funding to politicians across a range of parties to gain influence (e.g., [19]). Any deterioration of trust in the political system may be especially heightened among certain groups of smokers. There is some evidence of scepticism as to whether political parties truly care about them and their health, as they perceive the revenue raised through their tobacco purchasing as beneficial for the government [20]. This trust is also largely believed to be influenced by the media, including newspapers, who some suggest have the power to undermine the credibility of politicians [21].

In the same way there is a shared association between health, social disadvantage and voting, there may also be with newspaper readership. Social capital and status, income and health status are also known to be important predictors of newspaper readership [22-24], and newspaper readership is influential in voting - both through persuading readers and, in the UK, having standing affiliations with political parties during elections. While there is evidence on the relationship between health behaviours and newspaper readership from outside the UK, there is to date very little from within. To expand the literature in this field, we therefore also consider newspaper readership in a sensitivity analyses here.

For those facing health and social difficulties voting may not be a priority, and, when it is, a wider set of cultural factors may be perceived as more important to improving one's life than health. For some smokers, quitting smoking and improving one's health may be perceived as having little impact on one's lived circumstances. The relative health burden and inequalities caused by smoking and its related circumstances could lead to a type of 'political exclusion' inequality, making certain groups within the population uncountable and underrepresented [3]. 
Here we explore the association between smoking status, associated demographic (sex, age, social grade, region) and health characteristics (alcohol use) and voting intentions in England between 2015 and 2020. We also a measure of alcohol use as there is a strong association between smoking and alcohol consumption and alcohol use undermines quitting [25-27], thus alcohol may serve as another proxy health measure for voting intentions. These intentions were not bound to any specific election (i.e., 8th June 2017, 12th December 2019), instead the question was theoretical, asking "how would you vote if there was an election tomorrow?" UK Newspapers are widely perceived as right- or left-leaning, with newspaper readership reflecting broad political orientation. As voting intentions are sensitive to changes, depending on particular issues and leaders of political parties, we therefore include a sensitivity analysis here replacing voting intention with newspaper readership.

Using monthly cross-sectional data from the Smoking Toolkit Study, this study aimed to examine the association between smoking status and voting intentions. Specifically, we aimed to investigate two research questions:

1: Is there an association between smoking status (smoker, former-smoker, never smoker) and party voting intentions?

2: Is any association between voting intentions and smoking status independent of sociodemographic characteristics (sex, age, socioeconomic status as measured by occupational grade, region) and alcohol use?

\section{Methods \\ Design and setting}

Data were collected between February 2015 and February 2020 from the ongoing Smoking Toolkit Study (STS), a monthly repeated cross-sectional survey of a representative sample of adults in England [28]. The STS uses a hybrid of random location and quota sampling to select a new sample of approximately 1,700 adults (aged $\geq 16$ years) each month. Locations are randomly selected from around 170,000 output areas in England, stratified by a geodemographic classification of the population. Interviews are performed with one household member until quotas based on factors influencing the probability of being at home (e.g. sex, age, working status) are fulfilled. Comparisons with sales data and other national surveys show that the STS recruits a representative sample of the population in England with regards to key demographic variables, smoking prevalence, and cigarette consumption [19].

\section{Ethical approval and consent to participate}

Ethical approval for the STS was granted by the UCL Ethics Committee (ID 0498/001). All participants are treated in accordance with the principles of the Declaration of Helsinki. Written informed consent is obtained by all participants. The data is not collected by UCL and is anonymised when received by the research team.

\section{Measures \\ Outcome variable}

In order to measure party voting intentions, respondents were asked "How would you vote if there were a General Election tomorrow?" (1) Conservative (reference category; traditionally a right leaning party), (2) Labour (traditionally a left leaning party), (3) Liberal Democrat (considered a centrist party), (4) Green Party (traditionally a left leaning party), (5) UK Independence Party (right leaning party), (6) Other, (7) intended not to vote, (8) Undecided, (9) Refused.

\section{Explanatory variable}

Smoking status was determined by asking, "Which of the following best applies to you" (1) I smoke cigarettes (including hand-rolled) every day, (2) I smoke cigarettes (including hand-rolled), but not every day, (3) I do not smoke cigarettes at all, but I do smoke tobacco of some kind (e.g. pipe, cigar or shisha), (4) I have stopped smoking completely in the last year, (5) I stopped smoking completely more than a year ago, (6) I have never been a smoker (i.e. smoked for a year or more). Those who reported currently smoking cigarettes or tobacco of another type were considered to be a smoker. All of those who reported having stopped smoking within the last year or before were considered former smokers. All others were considered never-smokers.

\section{Covariates}

Sex was categorised by female/other, and age by category (16-24, 25-34, 35-44, 45-54, 55-64, and $\geq 65$ years).

\section{Occupational social grade}

As measured by the National Readership Survey [29], comprises $\mathrm{AB}$ (higher and intermediate managerial, administrative and professional), C1 (supervisory, clerical and junior managerial, administrative and professional), C2 (skilled manual workers), D (semi-skilled and unskilled manual workers) and $\mathrm{E}$ (state pensioners, casual and lowest-grade workers, unemployed with recourse to state benefits. 


\section{Region}

Region is presented by four divisions of England, North, Central, South and London.

\section{Alcohol}

The AUDIT [30] score was used as a continuous measure for alcohol drinking and associated behaviour and is a known confounder of associations between smoking and health outcomes. The AUDIT is a widely used measure of alcohol use designed to indicate alcohol use which is potentially harmful to health. A score between 0 and 7 indicate the lower risk category, scores of 8-15 indicate increasing risk, 16-19 higher risk and those of $20+$ indicate possible dependence.

\section{Newspaper readership}

Participants were asked which daily national newspaper they read regularly (e.g., Daily Mail, The Sun, The Telegraph, The Guardian, (list not exhaustive)).

\section{Analyses}

This study was preregistered on the Open Science Framework: https://osf.io/fq7rd/. Within the protocol current smoker was indicated as the reference category; however, because never smokers are the largest category this forms the reference category here instead. Analysis was conducted using SPSS v. 26. Data analysis was conducted on complete cases for all variables ( $<5 \%$ missing at random) and descriptive data were weighted to match the English population profile on age, social grade, region, tenure, ethnicity, and working status within sex. The dimensions are derived monthly from a combination of the English 2011 census, Office for National Statistics mid-year estimates, and an annual random probability survey conducted for the National Readership Survey.

\section{Causal pathways}

The covariate adjustment set was determined by constructing a directed acyclic graph (DAG) (Supplementary Fig. 1). Based on the published literature, the DAG illustrates the hypothesized causal and mediated pathways between smoking and observed health and social factors as well as unobserved latent factors, not able to be captured here, and their relationship to voting.

For research question 1, we used a multinomial regression model to estimate the unadjusted association (presenting the $95 \%$ confidence interval [CI]) between smoking status (never smoker as reference category) and voting intentions on unweighted data. The Conservative party was selected as the reference category because it was the government party at the time of data collection. For research question 2, we used a multinomial model to estimate the associations adjusting for AUDIT scores (as a continuous variable) and sociodemographic characteristics (categorical variables) on unweighted data. Across all models presented below, Goodness-of-fit tests indicated the full model statistically significantly predicted the dependent variable better than the intercept-only model alone (Likelihood ratio < 0.001). Independence of observations and multicollinearity were evaluated with simple correlations among the independent variables.

Sensitivity analysis: To assess the extent to which associations with voting intention reflect associations with political orientation, we planned to repeat the models with newspaper readership replacing party voting intention. However, from a visual inspection of the frequency with which people reported newspaper readership, the individual categories of newspapers did not correspond with voting intention. As there is a larger number and readership of right-leaning and mixed papers, we decided that because some papers have historically switched their leaning and to reduce skewness of right leaning, only two papers of each leaning, based on their clear political affiliation [31] would be selected for analysis. Guardian and Mirror were coded as left-leaning, Independent and Metro coded as centrist, and the Daily Express and Daily Mail as right-leaning, with mixed readership indicating readership across leanings.

\section{Results}

\section{Participant characteristics}

55,482 (complete cases) participants responded between 2015 and 2020 (51\% female $n=28,303$; mean age 47.37 years $(s d=1.7))$. Table 1 provides the weighted descriptive statistics by party voting intention. Respondents most commonly reported intending to vote Labour (27.1\%), with $19.8 \%$ Conservative, and a further $6.8 \%$ Liberal Democrats, although almost a quarter reported that they were undecided, with the remainder refusing to answer, not planning to vote or selecting an 'Other' party. In a follow-up question, responses indicated Green Party 2.6\%, UK Independence Party $1.8 \%$, other $0.7 \%$. and British National Party $0.5 \%$.

Prevalence of smoking status across the whole sample was, 65.4\% (95\% CI 65.43-66.12) never-smoker, 17.3\% (95\% CI 17.11 - 17.61) former-smoker, and 16.9\% (95\% CI 16.6-17.2) current smoker. Figure 1 presents smoking status prevalence by voting intentions; those intending not to vote represented the highest percentage of current smokers $27.4 \%$ (95\% CI 26.4-28.5) and the lowest of former smokers $13.8 \%$ (95\% CI 13.01-14.7\%). Conversely, those who refused to answer had the highest percentage of never smokers (73.5\%; 95\% CI 72.13-75.66), followed by those intending to vote Liberal Democrat $69.8 \%$ (95\% CI 68.22-71.32) who also represented the fewest current smokers $10 \%$ (95\% CI 9.09-11.16\%). Those intending 
Table 1 Descriptive data of participants by party voting intentions

\begin{tabular}{|c|c|c|c|c|c|c|c|c|}
\hline & Total & Conservative & Labour & Liberal Democrats & Other & Would not vote & Undecided & Refused \\
\hline$\%(n)$ & $100(55,482)$ & $19.8(11,006)$ & $27.1(15,013)$ & $6.2(3461)$ & $5.9(3266)$ & $12.2(6767)$ & $24.5(13,595)$ & $4.3(2375)$ \\
\hline \multicolumn{9}{|c|}{ Smoking status \% (n) } \\
\hline Never smoker & $65.4(36,237)$ & $65.8(7349)$ & $65.7(10,144)$ & $69.8(2358)$ & $57.3(1832)$ & $58.7(3841)$ & $67.1(8957)$ & $73.5(1756)$ \\
\hline Former-smoker & $18.2(9964)$ & $22.5(2515)$ & $16.5(2539)$ & $20.2(682)$ & $23.2(741)$ & $13.8(904)$ & $16.7(2236)$ & $14.5(347)$ \\
\hline Current smoker & 16.4 (9253) & $11.7(1302)$ & $17.8(2748)$ & $10(338)$ & $19.5(625)$ & $27.4(1793)$ & $16.2(2162)$ & $11.9(285)$ \\
\hline \multicolumn{9}{|c|}{$\begin{array}{l}\text { Newspaper readership } \\
\% \text { (n) }\end{array}$} \\
\hline Daily Mail & $32.7(3640)$ & $62(1612)$ & $13.9(523)$ & $17.5(128)$ & $32.3(229)$ & $32.2(238)$ & $33.8(739)$ & $37.5(171)$ \\
\hline Daily Express & $7.6(801)$ & $12.5(326)$ & $3.1(116)$ & $2.5(18)$ & $11.8(84)$ & $7.8(58)$ & $7.4(162)$ & $8.1(37)$ \\
\hline The Guardian & $27.1(2946)$ & $7(183)$ & $38.7(1454)$ & $54.5(398)$ & $31.2(221)$ & $17.2(127)$ & $21.8(476)$ & $19.1(87)$ \\
\hline Daily Mirror & $10.6(1341)$ & $6.3(164)$ & $16.8(632)$ & $5.3(39)$ & $6.7(48)$ & $15.5(115)$ & $13.4(292)$ & $11.2(51)$ \\
\hline The Independent & $1.2(153)$ & $1.1(27)$ & $1.7(64)$ & $1.2(9)$ & $2.3(16)$ & $0.9(7)$ & $1.3(29)$ & $0.2(1)$ \\
\hline Metro & 20.6 (2299) & $11.1(290)$ & $25.8(968)$ & 19 (139) & $15.7(111)$ & $26.4(195)$ & $22.3(487)$ & $23.9(109)$ \\
\hline \multicolumn{9}{|l|}{ Age } \\
\hline $16-24$ & 13.6 (8194) & $6.5(729)$ & 19.4 (2996) & $9.9(335)$ & $11.6(371)$ & $21.3(1392)$ & $15.8(2117)$ & $10.6(254)$ \\
\hline $25-34$ & 13.5 (8059) & $7.3(814)$ & $17.4(2690)$ & $10.2(346)$ & $11.5(368)$ & $21.4(1398)$ & $16.3(2184)$ & $10.8(259)$ \\
\hline $35-44$ & $14.1(7782)$ & 9.4 (1052) & $15.7(2427)$ & $15.5(523)$ & $13.4(428)$ & $16.2(1061)$ & 14.7 (1960) & $13.8(331)$ \\
\hline $45-54$ & $12.6(8049)$ & $13.7(1532)$ & $14.4(2225)$ & $16.8(568)$ & $16.7(534)$ & $13.8(900)$ & 14.4 (1927) & $15.2(363)$ \\
\hline $55-64$ & $16.2(8584)$ & $18.1(2022)$ & $13.8(2132)$ & $18.2(616)$ & $19.1(611)$ & 12.1 (789) & 14.9 (1995) & 17.5 (419) \\
\hline $65+$ & $27.5(14,817)$ & $45(5021)$ & $19.2(2970)$ & 29.3 (991) & 27.7 (886) & $15.3(1004)$ & $23.8(3179)$ & $32(766)$ \\
\hline \multicolumn{9}{|l|}{ Sex } \\
\hline Male & $51.2(27,875)$ & $54.9(6129)$ & $50.2(7757)$ & $51.6(1745)$ & $56.6(1809)$ & $50.6(3309)$ & $44.4(5930)$ & 50 (1196) \\
\hline Female & $48.8(27,610)$ & $45.1(5041)$ & $49.8(7683)$ & 48.4 (1634) & $43.4(1389)$ & $49.4(3235)$ & $55.6(7432)$ & 50 (1196) \\
\hline \multicolumn{9}{|l|}{$\begin{array}{l}\text { Occupation social } \\
\text { grade }\end{array}$} \\
\hline$A B$ & $26.5(13,140)$ & $31.4(3510)$ & $23.2(3581)$ & $43.6(1474)$ & $25.1(804)$ & 13 (849) & $23.2(3099)$ & $26(623)$ \\
\hline $\mathrm{C} 1$ & $34.2(19,150)$ & 35.9 (4006) & $34.6(5343)$ & $36(1217)$ & 34 (1086) & 28.9 (1889) & $35.8(4788)$ & $34.3(821)$ \\
\hline $\mathrm{C} 2$ & $18.6(10,535)$ & $17.9(2005)$ & $18.1(2795)$ & $10.6(357)$ & $21.2(677)$ & $24.7(1617)$ & $19.8(2646)$ & $18.3(438)$ \\
\hline $\mathrm{D}$ & $11.6(6563)$ & $8.7(973)$ & $13(2010)$ & $5.1(171)$ & $10.2(326)$ & $19.7(1290)$ & $12.5(1673)$ & $11.7(280)$ \\
\hline$E$ & 9.1 (5037) & $6.1(676)$ & $11.1(1711)$ & $4.7(160)$ & $9.5(205)$ & 13.7 (899) & $8.7(1156)$ & $9.6(230)$ \\
\hline \multicolumn{9}{|l|}{ Region } \\
\hline South of England & $23.9(12,606)$ & $29.6(3306)$ & 15.4 (2383) & $33.3(1125)$ & $26.4(845)$ & 18.3 (1199) & $24.4(3261)$ & $20.4(487)$ \\
\hline London & 17.4 (9601) & $10.4(1163)$ & 24.6 (3799) & $19.8(669)$ & $13.7(439)$ & $15.6(1018)$ & 14.7 (1969) & $22.7(544)$ \\
\hline Central England & $30.8(16,782)$ & $33.6(3747)$ & $25.1(3874)$ & $26(878)$ & 28.8 (919) & 35.6 (2329) & 31.4 (4189) & $35.4(846)$ \\
\hline North of England & $23.9(16,479)$ & 26.4 (2947) & 34.9 (5383) & $20.9(707)$ & $31.1(993)$ & 30.5 (1996) & 29.5 (3938) & $21.5(515)$ \\
\hline $\begin{array}{l}\text { AUDIT Score mean } \\
\text { score (SD) }\end{array}$ & 3.31 (3.72) & $3.36(3.64)$ & $3.41(4.03)$ & $4.00(3.767)$ & $4.00(4.05)$ & $2.97(4.02)$ & $3.08(3.57)$ & $2.39(3.07)$ \\
\hline
\end{tabular}

Data is weighted so does not equally match total across all variables

to vote Liberal Democrat and 'Other' had the highest AUDIT scores, although the mean score for all groups was within the lower risk drinking category (Table 1).

\section{RQ1: Voting intention}

In unadjusted analysis, compared with intending to vote Conservative, being undecided (OR 1.38 95\% CI[1.25 $1.45] p<0.001$ ), intending to vote Labour (OR 1.48 [1.381.52] $p<0.001)$, "Other" (OR 1.80 [1.61-2.00] $p<0.001)$ or intending not to vote (OR $2.57[2.38-2.79] p<0.001)$ was associated with higher odds to be a current - relative to never - smoker, while intending to vote Liberal Democrat (OR $0.78[0.69-0.81] p<0.001$ ) or refusal to answer (OR 0.59 [0.52-0.67] $p<0.001$ ) was associated with lower odds to be a current smoker (Table 2).

Compared with intending to vote Conservative, being undecided (OR0.73 [0.69-0.79] $p<0.001$ ), intending to vote Labour (OR 0.76 [0.71-0.81] $p<0.001$ ), Liberal Democrat (OR $0.88[0.80-0.96] \mathrm{p}=0.007)$, intending not vote (OR $0.71[0.65-0.78] p<0.001$ ) or refusal to answer (OR 


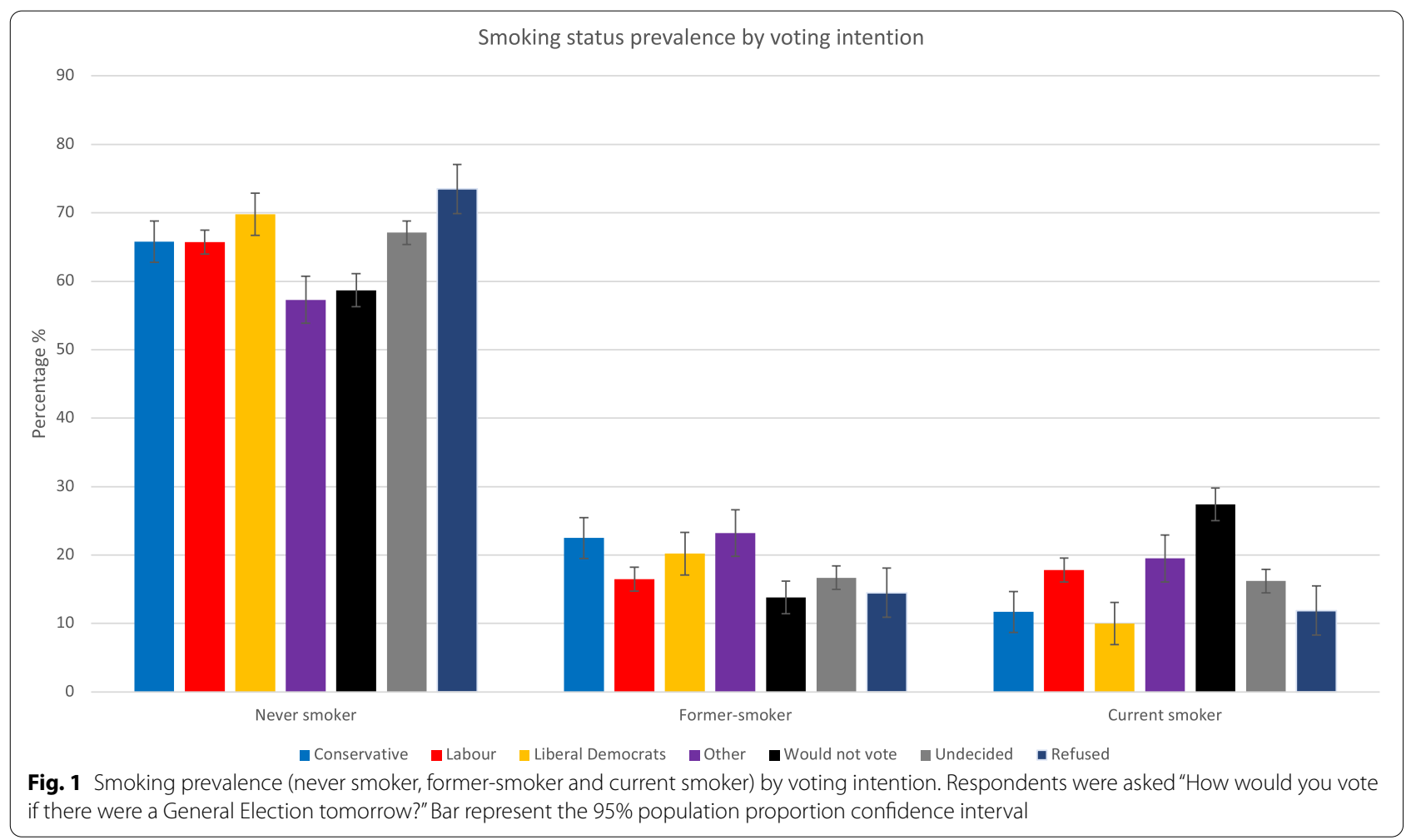

$0.59[0.52-0.67] p<0.001)$ was associated with a lower odds of former relative to never smoking, while 'Other' voting intention was associated with higher odds of former smoking (OR 1.17 (1.06-1.29) $p=0.002)$.

\section{RQ2: Voting intention (fully adjusted model)}

In fully adjusted analysis, compared with intending to vote Conservative, being undecided (aOR1.22 [1.131.33 < 0.001 ), intending to vote Labour (aOR1.27 [1.16$1.36]<0.001)$, "Other" (aOR1.54 [1.37-1.72]<0.001), or intending not to vote (aOR1.93 [1.77-2.11]<0.001) was associated with higher odds of smoking relative to never smoking (Table 2). Once more, intending to vote Liberal Democrat or refusing to answer was associated with lower odds of current smoking. Compared with intending to vote Conservative, intending to vote Labour (aOR1.10 (1.03-1.18) =0.006), intending note to vote $(\mathrm{aOR} 1.13(1.03-1.24)=0.007)$ and intending to vote 'Other' (aOR1.34 (1.21-1.48) <0.001) was each associated with a higher odds of former smoker status.

The results of the adjusted model including all prespecified covariates revealed a change in direction of odds ratio (OR) for associations between former compared with never smoking and intention to vote Labour, intending not to vote and undecided compared with Conservative, on running further exploratory analyses, this did not appear to be an artefact (see Supplementary Tables 1 and 2).

Furthermore, in the adjusted model compared with intending to vote Conservative, those intending to vote differently were likely to be younger, female (except intending not to vote), in social grades lower than $A B$, have a lower AUDIT score (except Liberal Democrat voters), and to reside in London.

\section{Sensitivity analysis}

In the subgroup of 24,047 respondents selecting one of the newspapers whose political orientation could be classified, the weighted prevalence of reporting reading right-leaning newspapers was 37.5\% (95\% CI 36.9-38.2), reported left-leaning 33\% (95\% CI 32.5-33.7), centrist 21.3\% (95\% CI 20.8-21.8) and mixed readership $8.1 \%$ (95\% CI 7.8-8.5). Figure 2 shows both centrist and mixed readers had the highest prevalence of current smokers, with $20.5 \%$ (95\% CI 19.51-21.51) and 20\% (95\% CI 18.54 - 21.75) respectively. Right-leaning readers had the fewest current smokers 12.3\% (95\% CI 11.69-12.2).

In fully adjusted model, compared with readers of right-leaning newspapers, left-leaning readers showed no difference in smoking status (Table 3). However, they were significantly more likely to have higher AUDIT scores, be of younger age, male and living in London and to report a social grade lower than $\mathrm{AB}$ (except E). 


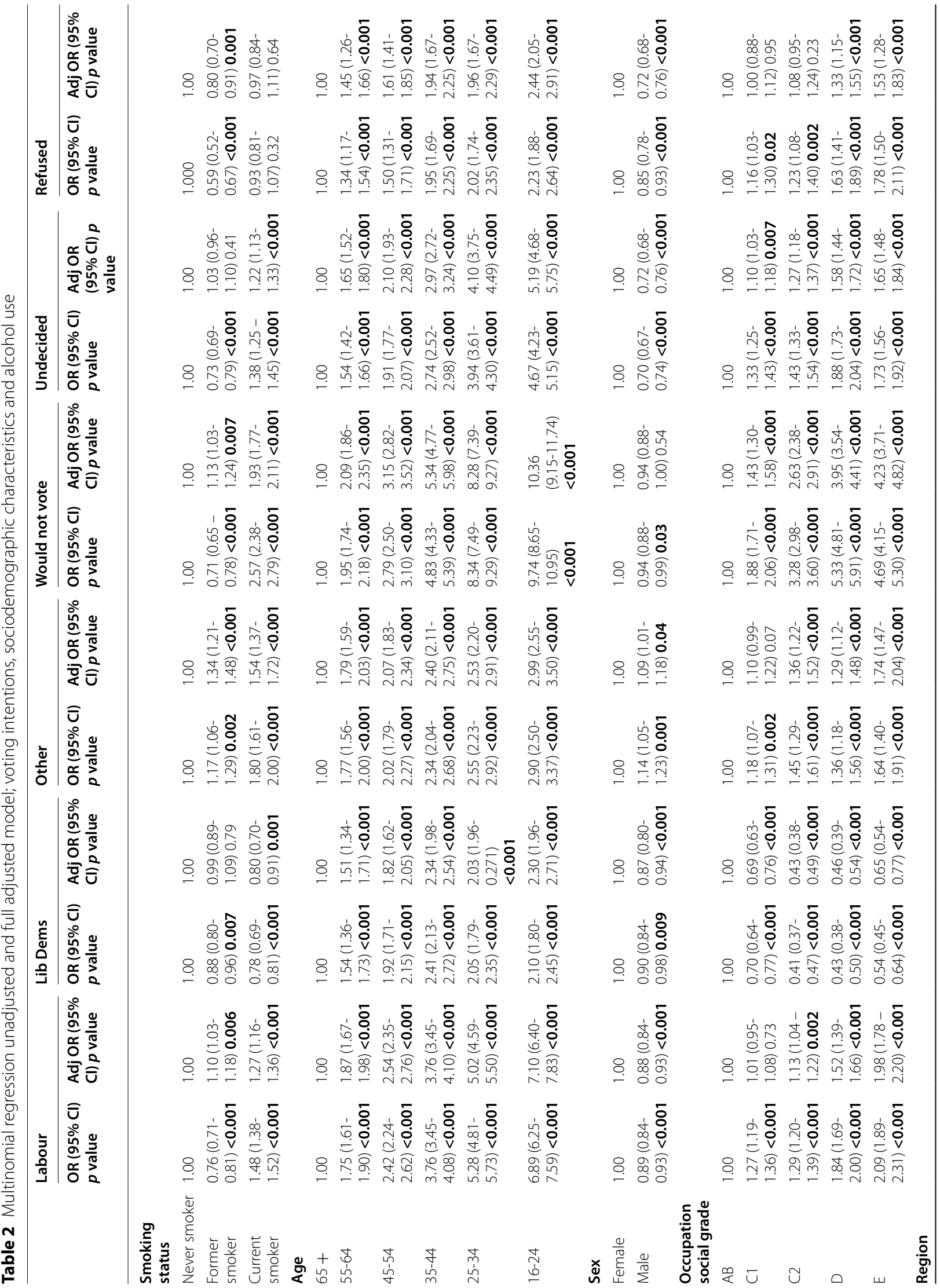




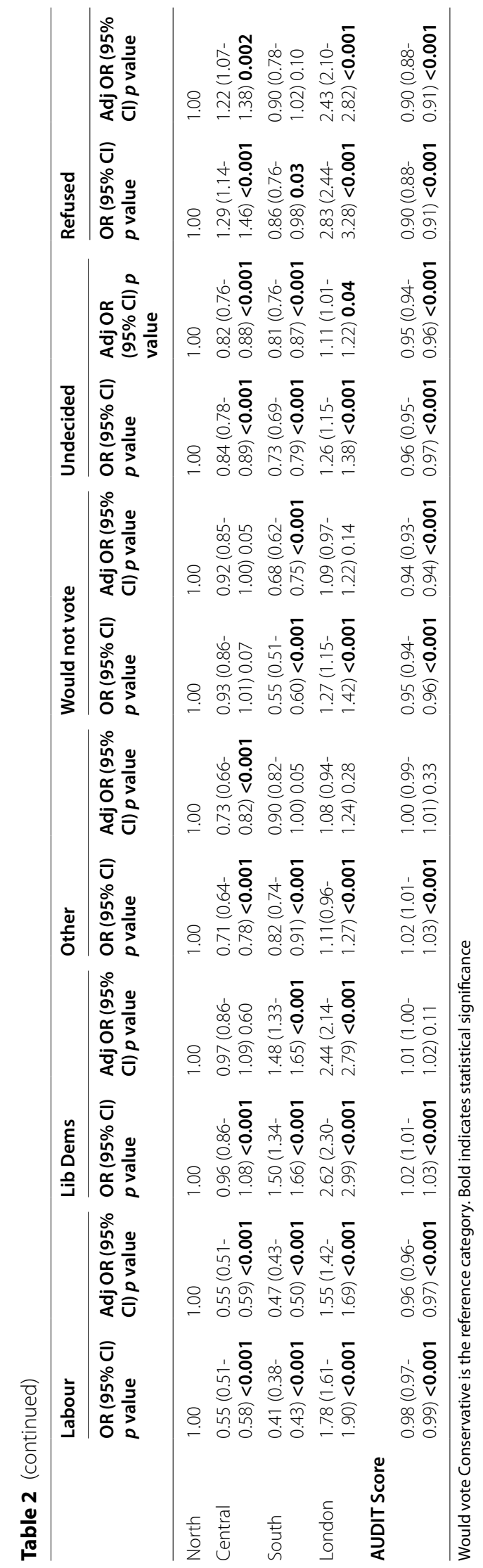




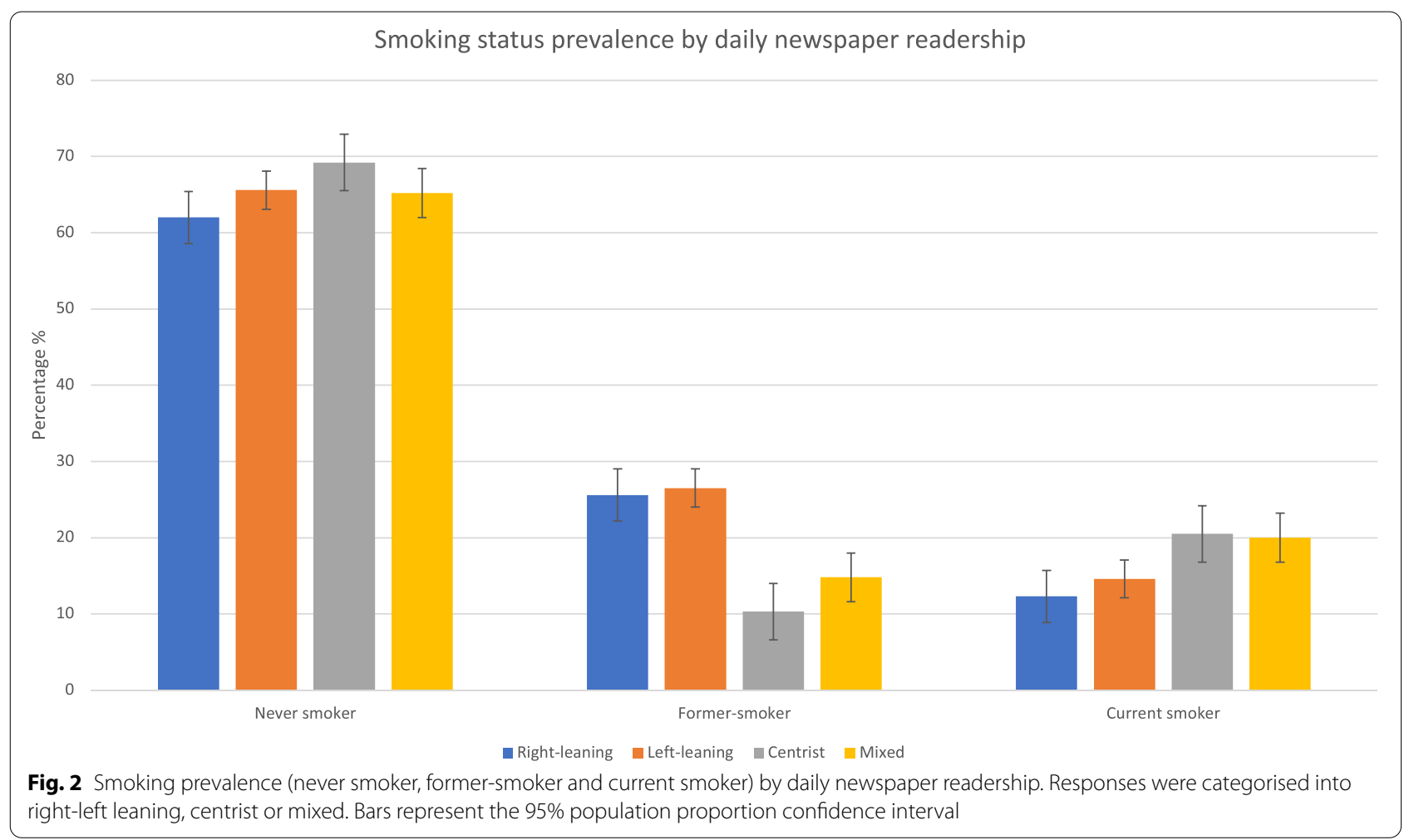

Centrist readers showed no difference in current smoking status or AUDIT scores compared with right-leaning readers but had significantly lower odds of being a former-smoker and higher odds of living in London, be male, younger and to report a higher social grade (AB). Mixed readers had significantly higher odds of being a current smoker (no difference in former-smoking status), and also had a higher AUDIT score, be younger and male, living in London and less likely to be in occupation grade lower than $\mathrm{AB}$ (except grade $\mathrm{E}$ ).

\section{Discussion}

Relative to those intending to vote Conservative, those intending to vote Labour, for a non-mainstream party and to not vote and those who were undecided were more likely to be smokers and those intending to vote Liberal Democrat were less likely to be smokers, after adjusting for sociodemographic characteristics and alcohol use. Those intending to vote Labour and to not vote, and those intending to vote for an 'Other' party, were also more likely to be former smokers compared with those intending to vote Conservative, after adjustment. In relation to newspaper readership, only mixed readership (defined as reading both left and right leaning newspapers) was associated with higher current smoking prevalence. While separately smoking and voting and smoking and newspaper readership show clear associations between smoking and political leanings, when taken together the results are mixed and smoking status cannot be clearly aligned with left, centrist or right leaning political views as a function of both voting intentions and readership.

Our results support previous research in several ways. Evidence from a study in England covering elections across three decades, as well as studies from Ireland, US and Sweden, all demonstrate a strong relationship with intending not to vote and smoking [1, 3, 18, 32]. In our study, $27.4 \%$ of those who intended not to vote reported being a current smoker and a low former-smoking prevalence rate $(13.8 \%)$. Moreover, these current smoking prevalence rates are in contrast to the average smoking prevalence rate in England of $16.5 \%$ over the same time period [14], highlighting in England at least, the association between not voting and smoking has remained strong. Current smoking prevalence estimates were also higher in those intending on voting for other parties or Labour (historically the Conservative's main opposition), and also those who were undecided (19.5\%, 17.8\%, and $16.3 \%$ respectively) compared with intending to vote Conservative. These represent key groups who are at a higher risk of tobacco related morbidity and mortality.

There are several implications from this study; by not voting smokers risk a 'political exclusion inequality', which may result in their health and social care needs 
Table 3 Multinomial regression unadjusted and full adjusted model; newspaper readership, sociodemographic characteristics and alcohol use

\begin{tabular}{|c|c|c|c|c|c|c|}
\hline & \multicolumn{2}{|l|}{ Left leaning } & \multicolumn{2}{|l|}{ Centrist } & \multicolumn{2}{|l|}{ Mixed } \\
\hline & $\begin{array}{l}\text { OR }(95 \% \mathrm{Cl}) p \\
\text { value }\end{array}$ & $\begin{array}{l}\text { Adj } \mathrm{OR}(95 \% \mathrm{Cl}) p \\
\text { value }\end{array}$ & $\begin{array}{l}\text { OR }(95 \% \mathrm{Cl}) p \\
\text { value }\end{array}$ & $\begin{array}{l}\text { Adj OR }(95 \% \mathrm{Cl}) p \\
\text { value }\end{array}$ & $\begin{array}{l}\text { OR }(95 \% \mathrm{Cl}) p \\
\text { value }\end{array}$ & $\begin{array}{l}\text { Adj OR }(95 \% \mathrm{Cl}) p \\
\text { value }\end{array}$ \\
\hline \multicolumn{7}{|l|}{ Smoking status } \\
\hline Never smoker & 1.00 & 1.00 & 1.00 & 1.00 & 1.00 & 1.00 \\
\hline Former smoker & $\begin{array}{l}0.83(0.78-0.89) \\
<0.001\end{array}$ & $1.00(0.92-1.07) 0.81$ & $\begin{array}{l}0.36(0.33-0.30) \\
<0.001\end{array}$ & $\begin{array}{l}0.74(0.65-0.83) \\
<0.001\end{array}$ & $\begin{array}{l}0.55(0.49-0.62) \\
<0.001\end{array}$ & $0.94(0.81-1.09) 0.41$ \\
\hline Current smoker & $\begin{array}{l}1.61(1.07-1.26) \\
<0.001\end{array}$ & $0.94(0.85-1.04) 0.23$ & $\begin{array}{l}1.50(1.38-1.63) \\
<0.001\end{array}$ & $1.09(0.97-1.22) 0.13$ & $\begin{array}{l}1.56(1.39-1.76) \\
<0.001\end{array}$ & $1.18(1.02-1.36) \mathbf{0 . 0 2}$ \\
\hline \multicolumn{7}{|l|}{ Age } \\
\hline $65+$ & 1.00 & 1.00 & 1.00 & 1.00 & 1.00 & 1.00 \\
\hline $55-64$ & $\begin{array}{l}1.63(1.50-1.76) \\
<0.001\end{array}$ & $\begin{array}{l}1.50(1.37-1.64) \\
<0.001\end{array}$ & $\begin{array}{l}3.82(3.34-4.36) \\
<\mathbf{0 . 0 0 1}\end{array}$ & $\begin{array}{l}3.52(3.02-4.10) \\
<0.001\end{array}$ & $\begin{array}{l}2.95(2.49-3.49) \\
<0.001\end{array}$ & $\begin{array}{l}2.53(2.09-3.05) \\
<\mathbf{0 . 0 0 1}\end{array}$ \\
\hline $45-54$ & $\begin{array}{l}2.47(2.27-2.69) \\
<0.001\end{array}$ & $\begin{array}{l}2.11(1.91-2.33) \\
<0.001\end{array}$ & $\begin{array}{l}10.78(9.51-12.22) \\
<\mathbf{0 . 0 0 1}\end{array}$ & $\begin{array}{l}8.44(7.29-9.77) \\
<0.001\end{array}$ & $\begin{array}{l}5.63(4.78-6.64) \\
<0.001\end{array}$ & $\begin{array}{l}4.46(3.71-5.36) \\
<0.001\end{array}$ \\
\hline $35-44$ & $\begin{array}{l}3.67(3.31-4.06) \\
<0.001\end{array}$ & $\begin{array}{l}3.06(2.72-3.43) \\
<0.001\end{array}$ & $\begin{array}{l}24.31(21.29-27.75) \\
<0.001\end{array}$ & $\begin{array}{l}16.00(13.70-18.68) \\
<0.001\end{array}$ & $\begin{array}{l}12.21(10.33-14.42) \\
<0.001\end{array}$ & $\begin{array}{l}8.79(7.28-10.62) \\
<0.001\end{array}$ \\
\hline $25-34$ & $\begin{array}{l}3.41(3.07-3.78) \\
<0.001\end{array}$ & $\begin{array}{l}2.68(2.38-3.02) \\
<0.001\end{array}$ & $\begin{array}{l}29.99(26.29-34.22) \\
<0.001\end{array}$ & $\begin{array}{l}15.59) 13.35-18.19) \\
<\mathbf{0 . 0 0 1}\end{array}$ & $\begin{array}{l}15.07(12.79-17.74) \\
<0.001\end{array}$ & $\begin{array}{l}9.48(7.85-11.43) \\
<0.001\end{array}$ \\
\hline $16-24$ & $\begin{array}{l}3.03(2.71-3.40) \\
<0.001\end{array}$ & $\begin{array}{l}2.58(2.27-2.94) \\
<\mathbf{0 . 0 0 1}\end{array}$ & $\begin{array}{l}28.66(24.99-32.88) \\
<0.001\end{array}$ & $\begin{array}{l}17.69(15.03-20.81) \\
<\mathbf{0 . 0 0 1}\end{array}$ & $\begin{array}{l}16.02(13.54-18.96) \\
<0.001\end{array}$ & $\begin{array}{l}11.83(9.74-14.38) \\
<0.001\end{array}$ \\
\hline \multicolumn{7}{|l|}{ Sex } \\
\hline Female & 1.00 & 1.00 & 1.00 & 1.00 & 1.00 & 1.00 \\
\hline Male & $\begin{array}{l}1.25(1.18-1.32) \\
<0.001\end{array}$ & $\begin{array}{l}1.14(1.07-1.22) \\
<0.001\end{array}$ & $\begin{array}{l}1.67(1.57-1.78) \\
<0.001\end{array}$ & $\begin{array}{l}1.58(1.46-1.72) \\
<0.001\end{array}$ & $\begin{array}{l}1.22(1.12-1.34) \\
<0.001\end{array}$ & $1.12(1.01-1.24) \mathbf{0 . 0 4}$ \\
\hline \multicolumn{7}{|c|}{$\begin{array}{l}\text { Occupation social } \\
\text { grade }\end{array}$} \\
\hline$A B$ & 1.00 & 1.00 & 1.00 & 1.00 & 1.00 & 1.00 \\
\hline $\mathrm{C} 1$ & $\begin{array}{l}0.71(0.66-0.76) \\
<0.001\end{array}$ & $\begin{array}{l}0.71(0.65-0.77) \\
<0.001\end{array}$ & $\begin{array}{l}1.44(1.32-1.57) \\
<0.001\end{array}$ & $\begin{array}{l}1.25(1.12-1.39) \\
<0.001\end{array}$ & $0.99(0.88-1.10) 0.79$ & $\begin{array}{l}0.84(0.73-0.95) \\
\mathbf{0 . 0 0 7}\end{array}$ \\
\hline $\mathrm{C} 2$ & $\begin{array}{l}0.59(0.54-0.63) \\
<0.001\end{array}$ & $\begin{array}{l}0.60(0.55-0.66) \\
<0.001\end{array}$ & $\begin{array}{l}1.57(1.43-1.72) \\
<0.001\end{array}$ & $\begin{array}{l}1.47(1.31-1.66) \\
<0.001\end{array}$ & $\begin{array}{l}0.74(0.65-0.84) \\
<0.001\end{array}$ & $\begin{array}{l}0.73(0.63-0.85) \\
<0.001\end{array}$ \\
\hline $\mathrm{D}$ & $\begin{array}{l}0.67(0.61-0.74) \\
<0.001\end{array}$ & $\begin{array}{l}0.70(0.63-0.78) \\
<0.001\end{array}$ & $\begin{array}{l}2.41(2.18-2.67) \\
<0.001\end{array}$ & $\begin{array}{l}2.16(1.89-2.48) \\
<0.001\end{array}$ & $\begin{array}{l}0.73(0.62-0.86) \\
<0.001\end{array}$ & $\begin{array}{l}0.69(0.57-0.84) \\
<0.001\end{array}$ \\
\hline E & $\begin{array}{l}0.80(0.71-0.90) \\
<0.001\end{array}$ & 0.95 (0.84-1.09) 0.49 & $\begin{array}{l}1.41(1.23-1.61) \\
<0.001\end{array}$ & $\begin{array}{l}1.94(1.62-2.32) \\
<0.001\end{array}$ & $0.83(0.68-1.01) 0.06$ & $1.06(0.84-1.33) 0.63$ \\
\hline \multicolumn{7}{|l|}{ Region } \\
\hline North & 1.00 & 1.00 & 1.00 & 1.00 & 1.00 & 1.00 \\
\hline Central & $\begin{array}{l}0.68(0.63-0.73) \\
<0.001\end{array}$ & $\begin{array}{l}0.77(0.70-0.84) \\
<\mathbf{0 . 0 0 1}\end{array}$ & $\begin{array}{l}0.73(0.66-0.82) \\
<\mathbf{0 . 0 0 1}\end{array}$ & $0.92(0.81-1.05) 0.20$ & $\begin{array}{l}0.66(0.58-0.76) \\
<\mathbf{0 . 0 0 1}\end{array}$ & $\begin{array}{l}0.80(0.68-0.94) \\
\mathbf{0 . 0 0 5}\end{array}$ \\
\hline South & $\begin{array}{l}0.65(0.61-71) \\
<0.001\end{array}$ & $\begin{array}{l}0.74(0.68-0.80) \\
<0.001\end{array}$ & $\begin{array}{l}0.69(0.62-0.77) \\
<0.001\end{array}$ & $1.01(0.89-1.15) 0.85$ & $\begin{array}{l}0.64(0.56-0.74) \\
<0.001\end{array}$ & $0.87(0.75-1.02) 0.80$ \\
\hline London & $\begin{array}{l}2.26(2.03-2.44) \\
<0.001\end{array}$ & $\begin{array}{l}2.16(1.95-2.40) \\
<0.001\end{array}$ & $\begin{array}{l}10.25(9.27-11.34) \\
<0.001\end{array}$ & $\begin{array}{l}8.02(7.08-9.08) \\
<\mathbf{0 . 0 0 1}\end{array}$ & $\begin{array}{l}5.06(4.46-5.75) \\
<0.001\end{array}$ & $\begin{array}{l}4.20(3.61-4.89) \\
<\mathbf{0 . 0 0 1}\end{array}$ \\
\hline \multicolumn{7}{|l|}{ AUDIT Score } \\
\hline & $\begin{array}{l}1.06(1.05-1.06) \\
<\mathbf{0 . 0 0 1}\end{array}$ & $\begin{array}{l}1.04(1.03-1.05) \\
<\mathbf{0 . 0 0 1}\end{array}$ & $\begin{array}{l}1.00(0.98-1.00) \\
<\mathbf{0 . 0 0 1}\end{array}$ & $1.00(0.99-1.01) 0.57$ & $\begin{array}{l}1.05(1.04-1.06) \\
<0.001\end{array}$ & $\begin{array}{l}1.03(1.02-1.04) \\
<\mathbf{0 . 0 0 1}\end{array}$ \\
\hline
\end{tabular}

Right-leaning is the reference category. Bold indicates statistical significance

not being met or prioritised as they lack political representation. This may create a vicious cycle in that by not voting, smokers may feel underrepresented and therefore feel less inclined to vote. For life long smokers, there is also a potential of being less able to vote in older life because of the physical barriers presented by tobaccorelated diseases and due to premature death, smokers will also be underrepresented in this demographic [33]. 
Furthermore, smokers are most represented in those working in occupational grades with lower incomes [13] and who experience structural disadvantages. As well as feeling left behind, as highlighted in the introduction, all parties need to work hard to gain the trust of smokers who may already feel that their tobacco purchasing is mutually beneficial for the government.

The current study provides a useful update to the literature but there are some limitations. Our question was hypothetical ('If there was an election tomorrow...) and we did not assess how and if people voted, nor did we adjust for psephologically relevant variables to accurately predict actual voting behaviour. Indeed, 27.1\% of our sample suggested they would for Labour but for the duration of the study period Conservatives were the party leading the country, and as such this could reflect the limitations of such a theoretical question or sampling bias. Further, our data were collected over what can be described as a turbulent political period with the Scottish independence referendum, the UK voting to leave the European Union and changes of leadership in several main parties. Consequently, people may have taken different viewpoints than they would have outside of this context. Another limitation is that while we show smoking was related to voting intentions and speculated this was linked to unhealthy behaviours, alcohol was not similarly associated (i.e AUDIT scores were higher among people intending to vote for the Liberal Democrat). This may be an example of the 'alcohol harm paradox' [34, 35]. It is commonly demonstrated in the UK that while hazardous drinking is more prevalent among more advantaged occupational grades, harm resulting from drinking is not, these social gradient effects on substance use and socio-political orientation warrant further unpacking. Lastly, the data here derive from a cross sectional survey and therefore do not follow temporal changes.

Future research can expand on these findings by including a wider range of health behaviours, including a more detailed analysis of alcohol use. We included newspaper readership as a sensitivity analysis only, but given the clear role newspapers have in political orientation this deserves more attention than could be given in this paper. For those particularly interested in political orientation and inclusion, the DAG is a useful visual of the environmental stressors individuals and communities face which may preclude them from considering voting for mainstream parties or from participating in elections.

In conclusion, controlling for a range of other factors, smokers as compared with never-smokers appear most likely to intend not to vote, to be undecided, to vote for Labour or a non-mainstream party, and appear least likely to vote for the Conservative Party or the Liberal Democrats. This relationship appears to be predicated on the basis of sociodemographic which separate smokers from those who vote for these two parties.

Abbreviation

DAG: Directed acyclic graph.

\section{Supplementary Information}

The online version contains supplementary material available at https://doi. org/10.1186/s12889-021-12304-4.

Additional file 1.

Acknowledgements

Not applicable.

Authors' contributions

RW, JB and FDV conceptualised the study. All authors contributed to the protocol and study analysis plan. SC and LS developed the study protocol, SC, EB and LS run the analysis. CMQ produced the initial DAG and all authors contributed to the final DAG. SC completed the first draft of the manuscript. All authors contributed to the final manuscript.

Funding

SC, JB and EB receive salary support from Cancer Research UK (C1417/A22962).

Availability of data and materials

The datasets used and/or analysed during the current study available from the corresponding author on reasonable request.

\section{Declarations}

Ethics approval and consent to participate

Ethical approval for the STS was granted by the UCL Ethics Committee (ID 0498/001). All participants are treated in accordance with the principles of the Declaration of Helsinki. Written informed consent is obtained by all participants.

\section{Consent for publication}

Not applicable.

\section{Competing interests}

SC, CMQ and FDV have no conflicts of interest to declare. EB and JB have received unrestricted research funding to study smoking cessation from companies who manufacture smoking cessation medications. RW is an unpaid director of the Unlocking Behaviour Change Community Interest Company. LS has received a research grant and honoraria for talk and travel expenses from manufacturers of smoking cessation medications (Pfizer and Johnson \& Johnson).

\section{Author details}

${ }^{1}$ Department of Behavioural Science and Health, University College London, 1-19 Torrington Place, London, UK. ${ }^{2}$ Population Health Sciences Institute, University of Bristol, Bristol, UK. ${ }^{3}$ NIHR School for Public Health Research, Bristol, UK.

Received: 25 May 2021 Accepted: 16 November 2021

Published online: 11 December 2021

References

1. Kelleher C, Timoney A, Friel S, McKeown D. Indicators of deprivation, voting patterns, and health status at area level in the Republic of Ireland. J Epidemiol Community Health. 2002;56(1):36. Available from: http://jech. bmj.com/content/56/1/36.abstract 
2. Holbein JB, Schafer JP, Dickinson DL. Insufficient sleep reduces voting and other prosocial behaviours. Nat Hum Behav. 2019;3(5):492-500. [cited 2020 Oct 19] Available from: http://www.nature.com/articles/ s41562-019-0543-4

3. Smith GD, Dorling D. I'm all right, John': voting patterns and mortality in England and Wales, 1981-92. BMJ. 1996;313(7072):1573-7. [cited 2021 Feb 1] Available from: https://www.bmj.com/lookup/doi/https://doi.org/ 10.1136/bmj.313.7072.1573

4. Denny KJ, Doyle OM. .... Take up thy bed, and vote" Measuring the relationship between voting behaviour and indicators of health. Eur J Public Health. 2007;17(4):400-1. [cited 2020 Oct 19] Available from: https://doi. org/10.1093/eurpub/ckm002

5. Bartley M. Health inequality: an introduction to concepts, theories and methods. Second edition. Cambridge, UK; Malden, MA, USA: Polity; 2017. $244 \mathrm{p}$.

6. Jha P, Peto R, Zatonski W, Boreham J, Jarvis MJ, Lopez AD. Social inequalities in male mortality, and in male mortality from smoking: indirect estimation from national death rates in England and Wales, Poland, and North America. The Lancet. 2006;368(9533):367-70. [cited 2020 Oct 5] Available from: https://linkinghub.elsevier.com/retrieve/pii/S014067360 6689757

7. Marmot M. Health equity in England: the Marmot review 10 years on. BMJ. 2020;m693. [cited 2020 Oct 19] Available from: https://www.bmj. com/lookup/doi/https://doi.org/10.1136/bmj.m693

8. Shortt NK, Tisch C, Pearce J, Mitchell R, Richardson EA, Hill S, et al. A cross-sectional analysis of the relationship between tobacco and alcohol outlet density and neighbourhood deprivation. BMC Public Health. 2015;15(1):1014. [cited 2021 Feb 1] Available from: http:// bmcpublichealth.biomedcentral.com/articles/https://doi.org/10.1186/ s12889-015-2321-1

9. lacobucci G. Stop smoking services: BMJ analysis shows how councils are stubbing them out. BMJ. 2018;k3649. [cited 2021 Feb 1] Available from: https://www.bmj.com/lookup/doi/https://doi.org/10.1136/bmj.k3649

10. Jarvis MJ, Wardle J. Social patterning of individual health behaviours: the case of cigarette smoking. In: Social determinants of health, 2. 1999. p. 224-37.

11. Hiscock R, Bauld L, Amos A, Fidler JA, Munafò M. Socioeconomic status and smoking: a review: Hiscock et al. Ann N Y Acad Sci. 2012;1248(1):10723. [cited 2020 Nov 3] Available from: https://doi.org/doi.wiley.com/10. 1111/j.1749-6632.2011.06202.x

12. Di Cesare M, Khang Y-H, Asaria P, Blakely T, Cowan MJ, Farzadfar F, et al. Inequalities in non-communicable diseases and effective responses. The Lancet. 2013;381 (9866):585-97. [cited 2020 Nov 3] Available from: https:// linkinghub.elsevier.com/retrieve/pii/S0140673612618510

13. Garnett C, Tombor I, Beard E, Jackson SE, West R, Brown J. Changes in smoker characteristics in England between 2008 and 2017. Addiction. 2020;115(4):748-56. [cited 2020 Oct 13] Available from: https://onlinelibr ary.wiley.com/doi/abs/https://doi.org/10.1111/add.14882

14. West R, Kale D, Brown J. Monthly trends on smoking in England from the Smoking Toolkit Study. The Smoking Toolkit Study; 2020 [cited 2020 Sep 20]. Available from: http://www.smokinginengland.info/latest-statistics/

15. Dawkins L, Ford A, Bauld L, Balaban S, Tyler A, Cox S. A cross sectional survey of smoking characteristics and quitting behaviour from a sample of homeless adults in Great Britain. Addict Behav. 2019;95:35-40. [cited 2020 Dec 15] Available from: https://linkinghub.elsevier.com/retrieve/pii/ S0306460318312632

16. Go big. Go local. The UK2070 report on a new deal for levelling up the United Kingdom. [Internet]. UK2070 Commission; 2020. Available from: https://uk2070.org.uk/wp-content/uploads/2020/09/Go-Big-Go-Local.pdf

17. Zeitoun J-D, Faron M, de Vaugrigneuse S, Lefèvre JH. Health as an independent predictor of the 2017 French presidential voting behaviour: a cross-sectional analysis. BMC Public Health. 2019;19(1):1468. [cited 2020 Oct 19] Available from: https://bmcpublichealth.biomedcentral.com/artic les/https://doi.org/10.1186/s12889-019-7861-3

18. Lindström M. Social capital, political trust and daily smoking and smoking cessation: A population-based study in southern Sweden. Public Health. 2009;123(7):496-501. [cited 2021 Feb 18] Available from: https://linki nghub.elsevier.com/retrieve/pii/S003335060900167X

19. Tobacco Tactics. Tobacco Industry Hospitality for UK Politicians. University of Bath; [cited 2021 Oct 14]. Available from: https://tobaccotactics.org/ wiki/tobacco-industry-hospitality-for-uk-politicians/
20. Wiltshire S, Bancroft A, Amos A, Parry O. 'They're doing people a service' qualitative study of smoking, smuggling, and social deprivation. BMJ. 2001;323(7306):203-7. [cited 2021 Oct 14] Available from: https://www. bmj.com/lookup/doi/https://doi.org/10.1136/bmj.323.7306.203

21. Park A, Curtice J, Thomson K, Phillips M, Johnson M, Clery E. British Social Attitudes: The 24th Report. 1 Oliver's Yard, 55 City Road, London England EC1Y 1SP United Kingdom: SAGE Publications Ltd; 2008 [cited 2021 Oct 14]. Available from: http://methods.sagepub.com/book/british-social-attit udes-the-24th-report

22. Chan TW, Goldthorpe JH. Social Status and Newspaper Readership. Am J Sociol. 2007;112(4):1095-134. [cited 2021 Oct 15] Available from: http:// www.journals.uchicago.edu/doi/10.1086/508792

23. Burgoon JK, Burgoon M. Predictors of Newspaper Readership. Journal Q. 1980;57(4):589-96. [cited 2021 Oct 15] Available from: http://journals. sagepub.com/doi/10.1177/107769908005700406

24. Veenstra G. Social capital, SES and health: an individual-level analysis. Soc Sci Med. 2000;50(5):619-29. [cited 2021 Oct 15] Available from: https:// linkinghub.elsevier.com/retrieve/pii/S027795369900307X

25. Kaner EFS, Dickinson HO, Beyer FR, Campbell F, Schlesinger C, Heather N, et al. Effectiveness of brief alcohol interventions in primary care populations. Cochrane Drugs and Alcohol Group, editor. Cochrane Database Syst Rev. 2007 [cited 2021 Oct 14]; Available from: https://doi.org/doi. wiley.com/10.1002/14651858.CD004148.pub3

26. Hughes JR, Kalman D. Do smokers with alcohol problems have more difficulty quitting? Drug Alcohol Depend. 2006;82(2):91-102. [cited 2021 Jun 21] Available from: https://linkinghub.elsevier.com/retrieve/pii/S0376 871605002747

27. Kahler CW, Spillane NS, Metrik J. Alcohol use and initial smoking lapses among heavy drinkers in smoking cessation treatment. Nicotine Tob Res. 2010;12(7):781-5. [cited 2021 Jun 21] Available from: https://academic. oup.com/ntr/article-lookup/doi/https://doi.org/10.1093/ntr/ntq083

28. Fidler JA, Shahab L, West O, Jarvis MJ, McEwen A, Stapleton JA, et al. 'The smoking toolkit study': a national study of smoking and smoking cessation in England. BMC Public Health. 2011;11(1):479. [cited 2020 Sep 27] Available from: http://bmcpublichealth.biomedcentral.com/artic les/https://doi.org/10.1186/1471-2458-11-479

29. National Readership Survey - Social Grade.." NRS; 2017.

30. Saunders JB, Aasland OG, Babor TF, De La Fuente JR, Grant M. Development of the Alcohol Use Disorders Identification Test (AUDIT): WHO Collaborative Project on Early Detection of Persons with Harmful Alcohol Consumption-II. Addiction. 1993;88(6):791-804. [cited 2021 May 21] Available from: https://doi.org/doi.wiley.com/10.1111/j.1360-0443.1993. tb02093.x

31. Smith M. How left or wight-wing are the UK's newspapers?. YouGov. 2017 [cited 2021 Mar 12]. Available from: https://yougov.co.uk/topics/politics/ articles-reports/2017/03/07/how-left-or-right-wing-are-uks-newspapers

32. Albright K, Hood N, Ma M, Levinson AH. Smoking and (Not) Voting: The Negative Relationship Between a Health-Risk Behavior and Political Participation in Colorado. Nicotine Tob Res. 2016;18(3):371-6. [cited 2020 Oct 19] Available from: https://academic.oup.com/ntr/article-lookup/ doi/https://doi.org/10.1093/ntr/ntv098

33. Bronnum-Hansen H. Abstention from smoking extends life and compresses morbidity: a population based study of health expectancy among smokers and never smokers in Denmark. Tob Control. 2001;10(3):273-8. [cited 2021 Mar 12] Available from: https://tobaccocon trol.bmj.com/lookup/doi/https://doi.org/10.1136/tc.10.3.273

34. Lewer D, Meier P, Beard E, Boniface S, Kaner E. Unravelling the alcohol harm paradox: a population-based study of social gradients across very heavy drinking thresholds. BMC Public Health. 2016;16(1):599. [cited 2021 Mar 12] Available from: http://bmcpublichealth.biomedcentral.com/artic les/10.1186/s12889-016-3265-9

35. Beard E, Brown J, West R, Angus C, Brennan A, Holmes J, et al. Deconstructing the Alcohol Harm Paradox: A Population Based Survey of Adults in England. Ciccozzi M, editor. PLOS ONE. 2016;11(9):e0160666. [cited 2021 Mar 12] Available from: https://doi.org/dx.plos.org/10.1371/journal. pone. 0160666

\section{Publisher's Note}

Springer Nature remains neutral with regard to jurisdictional claims in published maps and institutional affiliations. 